\section{Bem Viver do Cerrado: aspectos de uma bioética local}

Floriano, J

Doutoranda do Programa de Pós-Graduação em Bioética da Universidade de Brasília. E-mail: ginecologiautonoma@gmail.com

PALAVRAS CHAVE: Pluralismo Bioético; Bem Viver; Cerrado; Conhecimentos Tradicionais; Parteiras Tradicionais

Introdução Abya Yala é formada por povos com uma rica diversidade histórica cultural que convivem em um mesmo território com pluralidades de formas de entender, viver e sonhar a vida. As bioéticas latino-americanas vêm trazendo a importância do pluralismo no sentindo de abordar as questões éticas a partir das realidades concretas, e com conceitos próprios. O Cerrado é a savana com maior biodiversidade do mundo, bioma que abriga dez estados brasileiros e o Distrito Federal. Por essas terras milenárias passaram e viverem muitos povos, que fazem parte do equilíbrio no bioma. Deste contexto emanam bioéticas com mais afinidade às questões regionais e que podem ampliar o arcabouço teórico e a práxis da bioética em outras regiões. Método Foi feita uma pesquisa qualitativa com a parteira e raizeira Dona Flor da comunidade quilombola do Moinho em Alto Paraíso/GO. A metodologia foi ancorada em princípios da educação biocêntrica que propõe como método uma prática pedagógica reflexiva e vivencial, onde aprendizagem se dá tanto pelo racional como pelas emoções, sentimentos, sensações e intuição [1]. A bioética dessa mestra pôde ser vista manifestada em outras pessoas dos quilombos da Chapada dos Veadeiros, através do convívio cotidiano da pesquisadora com essas pessoas. A pesquisa foi feita entre 2014 e 2016 com aprovação pelo CEP/CONEP via Plataforma Brasil. Seus resultados são trabalhados em profundidade na dissertação de mestrado da autora [2]. Resultados A destruição da diversidade e a criação da uniformidade envolvem simultaneamente a destruição da estabilidade e a criação da vulnerabilidade [3] socioambiental e cultural. As mestras e mestres do conhecimento tradicional e popular são fundamentais para a autonomia da vida comunitária e para o bem viver de suas e de outras comunidades. São, portanto, guardiãs e guardiões da sociobiodiversidade. Ressalta-se aqui a importância específica das parteiras tanto pelas práticas sofisticadas em saúde da família como pela contribuição filosófica à bioética. Com relação a este último aspecto, identificou-se seis elementos como ativadores corporais de bioética, ou seja, que ativam e despertam o corpo para a consciência e atitudes éticas: o amor, a espiritualidade, as flores, os doces, a música e o tempo da terra. Desses elementos se desdobram possíveis aspectos da bioética do Cerrado: a ética de cura; o pluriverso comunitário e a valorização do antigo. Esses elementos somados a outros constituem o que se propõe chamar de Bem Viver do Cerrado. Conceito que carrega um potencial de reivindicação para os movimentos sociais e povos do Cerrado. Conclusões $\mathrm{O}$ que as populações tradicionais e comunidades populares vem nos ensinando é que a bioética não pode ser estritamente racional, a formulação de argumentos passa por uma relação corporal com o cosmos, com os seres não humanos e com o mundo invisível. Algo que vem sendo trabalho por algumas pensadoras da bioética [4][5][6]. O pluralismo bioético pode ser um caminho de (re)pensar e (re)sentir aqueles saberes que foram marginalizados com o entendimento de que só assim se poderá encontrar estratégias normativas e interventivas que garantam a vivência de projetos de vidas baseados nesses saberes, ou seja, de vidas plurais.

AGRADECIMENTOS. À Coordenação de Aperfeiçoamento de Pessoal de Nível Superior - Brasil (CAPES) - Código de Financiamento 001; à Dona Flor e sua família; à comunidade kalunga; a Wanderson Flor do Nascimento; à Angela Aparecida Donini; à Tatiana Nascimento dos Santos; à Rita Laura Segato.

\section{REFERÊNCIAS}

[1] R. Cavalcante, 2007, 10 apud J. Lopes. Experimentações em Cultura, Educação e Cidadania: O Caso da Associação Grãos de Luz e Griô. (Dissertação) Rio de Janeiro: FGV CPDOC - Programa de Pós-Graduação em História, Política e Bens Culturais, 2009.

[2] J. Floriano. Bem viver do cerrado: partejar amor, parir uma bioética local. [Dissertação] Programa de PósGraduação em Bioética. Brasília: Universidade de Brasília, 2016.

[3] V. Shiva. Monoculturas da mente: perspectivas da biodiversidade e da biotecnologia. Trad. Dinah de Abreu Azevedo. Gaia: São Paulo, 2003.

[4] Z. Osman. Bio-ética islâmica: Aportes Epistemológicos desde o Pensamento Decolonial e os Feminismos Islâmicos. (Dissertação) Programa de Pós-Graduação em Bioética. Brasília: Universidade de Brasília, 2015.

[5] M. Holanda. Por uma ética da (In)Dignação: repensando o Humano, a Dignidade e o pluralismo nos movimentos de lutas por direitos. (Tese) Programa de Pós-Graduação em Bioética, Faculdade de Saúde, Universidade de Brasília, 2015. 